\title{
Sera Isı Gereksinimi Hesaplama Modelinin "ISIGER-SERA” Çukurova Koşullarında Test Edilmesi
}

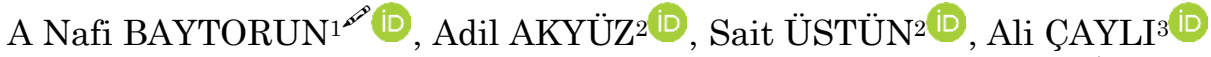 \\ ${ }^{1}$ Çukurova Üniv. Ziraat Fak. Biyosistem Müh. Böl., Adana, ${ }^{2}$ Kahramanmaraş Sütçü İmam Üniv. Ziraat Fak. Biyosistem Müh. Böl., \\ Kahramanmaraş, ${ }^{3}$ Kahramanmaraş Sütçü İmam Üniv. Türkoğlu MYO., Bitkisel Üretim Böl., Kahramanmaraş \\ 凹: baytorun@cu.edu.tr
}

\section{ÖZET}

Serada ısı gereksinimi, seranın tipine, donanımına, sera kurulacak yerin iklimine ve bitkilerin arzu ettiği sıcaklığa bağlıdır ve DIN EN 13032 (Eskiden DIN 4701) standartlarında belirtilen esaslara göre hesaplanmaktadır. Seralarda ısı gereksinim hesaplamaları daha çok günlük ortalama sicaklık değerlerinden gidilerek yapılmaktadır. Ancak günlük ortalama sıcaklık değerlerine göre yapılan hesaplamalar gerçek değerlerden farklılıklar göstermektedirler. Seralarda ısı tüketiminin belirlenmesinde en sağlıklı değerler saatlik iklim değerlerinden (sıcaklık, güneş radyasyonu ve rüzgâr) gidilerek yapılan hesaplamalarla elde edilmektedir.

Seralarda ısı gereksinimi aynı zamanda sera donanımına bağlı olarak değişmektedir. Seralarda kullanılan ısıtma sistemlerinin tipi ile ısı tasarrufu amaciyla kullanılan isı perdelerinin tipi ve sızdırmazlıkları ısı gereksinimine etki eder. Ayrıca gün boyu serada depolanan ısı enerjisi serada sıcaklık yükselmelerine neden olmaktadır. ISIGER-SERA uzman sistem modeli belirtilen tüm bu etkileri dikkate alarak seralarda ısı gereksinimi hesaplamaktadır. Yapılan bu çalışmada ISIGER-SERA uzman sistem modelinin Akdeniz iklim kuşağında (Adana) üretici koşullarında kurulmuş yüksek teknolojiye sahip serada test edilmesi amaçlanmıştır. Elde edilen sonuçlar ISIGER-SERA uzman sistem modeliyle teorik olarak hesaplanan isı enerjisi gereksinimi ile gerçekte serada tüketilen ısı enerjisi arasında \% 3’lük bir fark olduğu belirlenmiştir.
DOI:10.18016/ksudobil.396127

\section{Makale Tarihçesi}

Geliş Tarihi : 16.02.2018

Kabul Tarihi :06.04.2018

\author{
Anahtar Kelimeler \\ ISIGER-SERA, \\ Sera, \\ Sera 1sitması, \\ Isı enerjisi gereksinimi, \\ Isı perdesi
}

\section{Araştırma Makalesi}

\section{Testing Greenhouse Heat Requirement Calculation Model "ISIGER-SERA" in Cukurova Conditions}

\section{ABSTRACT}

Heat requirement of greenhouse, calculated according to the principles specified in DIN EN 13032 (formerly DIN 4701) standards, depends on the type of greenhouse, the equipment, climate condition of greenhouse location, and the optimum growth temperature of plants. The heat requirement calculations are usually performed using mean values of daily temperature. However, calculations based on daily average temperature values shows difference from actual values. Determination of optimal heat consumption values in greenhouse were observed when hourly climate values (temperature, solar radiation, and wind) were used. Also, the heat requirement of greenhouses depends on the greenhouse equipments. The type of used heating systems, type of heat curtains used for heat saving and their leaks affect the heat requirement. During the day heat energy was stored and causes temperature increasing in greenhouse. The ISIGER-SERA expert system model calculates the heat requirement in the greenhouse taking into account all these effects mentioned. In this study, it is aimed to test the ISIGER-SERA expert system model in high technology established producer greenhouse located Mediterranean climate zone (Adana). Results showed that only 3\% differences were

\section{Article History}

Received : 16.02.2018

Accepted : 06.04.2018

\author{
Keywords \\ ISIGER-SERA, \\ Greenhouse, \\ Greenhouse heating, \\ Heat energy requirement, \\ Heat curtain
}

\section{Research Article}


observed between calculated heat energy requirement with ISIGERSERA expert system model and the actual consumed heat energy in greenhouse.

To cite : Baytorun, AN, Akyüz A, Üstün S., Çaylı A 2018. Sera Isı Gereksinimi Hesaplama Modelinin "ISIGER-SERA" Çukurova Koşullarında Test Edilmesi. KSÜ Tarım ve Doğa Derg 21(5): 699-707. DOI:10.18016/ksudobil.396127.

\section{GİİŞ}

Seralar kuruldukları yerin iklimine bağlı olarak, farklı dönemlerde isitma, havalandırma, gölgeleme ve/veya soğutma gereksinimi gösterirler. Isitma, verim ve kaliteyi olumlu yönde etkilerken, üretim maliyetinin yükselmesine neden olmaktadır. Isitma giderleri sera yapısına, donanımına ve yöre iklimine bağlı olarak işletme giderlerinin \% 20-60 arasında değişmektedir (Baytorun ve ark., 2017). Serada ısı gereksinimi, seranın tipine, donanımına, sera kurulacak yerin iklimine ve bitkilerin arzu ettiği sıcaklığa bağlı olarak DIN EN 13032 (Eskiden DIN 4701) standartlarında belirtilen esaslara göre hesaplanmaktadır. Seralarda ısı gereksinimi daha çok ortalama sıcaklık değerlerine göre hesaplanmaktadır. Ancak sicaklığın yüksek olduğu geçiş dönemlerinde ve serada sıcaklığın düşük tutulduğu koşullarda, ortalama sıcaklık değerlerinden gidilerek yapılan hesaplamalar hatalı sonuçlar vermektedir (Baytorun ve ark., 2016b; Tantau, 1983). Dış sıcaklık ortalamasının $16{ }^{\circ} \mathrm{C}$ olduğu koşullarda, serada sicaklığın $16{ }^{\circ} \mathrm{C}$ olarak arzu edilmesi durumunda, serada isitmaya gerek olmadığı ortaya çıkmaktadır. Oysa ortalama $16{ }^{\circ} \mathrm{C}$ bu değerin altında ve üstünde sıcaklık değerlerini kapsamaktadır. Belirtilen nedenle sicaklık ortalamasının yüksek olduğu dönemlerde günün belirli saatlerinde isitmaya gereksinim duyulmasına karşın alınan ortalama değer nedeniyle ısı gereksinimi hesaplanmamaktadır.

Seralarda isı gereksinimi hesaplamaları farklı şekillerde yapılmaktadır. Öztürk (2011) Antalya ilindeki seralar için ısıtma gereksinimi duyulan her ayın en düşük sıcaklık değerlerine bağlı olarak belirlediği ısı gücü değerlerinin ortalaması ve serada yapılacak ısıtma süresini varsayarak ısı gereksinimini belirlemiştir. Canakci ve ark. (2013) Antalya için ısı enerjisi gereksinimini gece saatlerinde ortaya çıkan sıcaklık ortalamalarını ve gece uzunluğunu göz önüne alarak hesaplamışlardır.

Damrath ve Klein (1983), Trier (Almanya) için ısı enerjisi gereksinimini saatlik değerlerden giderek DIN 4701 standartlarinda belirtilen esaslara göre hesaplamışlardır. Damrath (1980) yaptı̆̆ı çalışmada ısı gereksinimini her yıl için saatlik olarak hesapladığ değerlerin uzun yıllar ortalamasını alarak belirlemiştir.

Von Zabeltitz (2011) eserinde Akdeniz ülkelerindeki plastik seralar için ısı enerjisi gereksinimini, Hallaire (1950)'in yöntemini kullanarak en düşük sıcaklık değerlerine ve bölgenin enlem derecesine bağlı gün uzunluğu değerlerinden giderek hesaplamıştır. Von
Zabeltitz (2011) aynı eserinde serada ısı enerjisi gereksiniminin saatlik iklim değerlerinden gidilerek en doğru şekilde hesaplanacağını ifade etmiştir.

Üstün (1993), Baytorun ve ark. (2012) yaptıkları çalışmada Adana, Önder (1998) Antakya ili için HORTEX uzman sistemi (Rath, 1992) yardımı ile saatlik değerlerden giderek gerekli olan yakıt tüketimlerini hesaplamışlardır.

Seraların ısı enerjisi gereksinimi, saatlik verilerine göre hesaplanan ısı gücü değerlerinin toplamına eşittir (Meyer, 2008). DIN EN 13032 standartlarinda belirlenen esaslara göre saatlik iklim değerlerinden gidilerek yapılan ısı gücü hesaplamalarında serada arzulanan sıcaklık ve dış sıcaklık değerleri arasındaki fark esas alınmaktadır. Ancak ısıtılmayan ve belirli bir sıcaklığa kadar havalandırılmayan seralarda ortaya çıkan sıcaklık, serada depolanan güneş enerjisi nedeniyle dış sıcaklık değerlerinden daha yüksektir (Rath, 1992). Gün boyu serada depolanan ısı enerjisi, serada sıcaklık yükselmesine neden olmaktadır. Bu nedenle seranın ısı depolama özelliğine göre, ısı gereksinimi için yapılacak hesaplamalarda, serada ortaya çıkan sıcaklık yükselmelerinin de göz önüne alınması, daha doğru sonuçların elde edilmesine olanak sağlamaktadır (Baytorun ve ark., 2016a; Rath, 1992; Tantau, 2008). Serada ortaya çıkan sıcaklık yükselmesi, gündüz saatlerindeki sıcaklık ortalamaları ile takip eden gece saatlerinin sıcaklık ortalamaları farkına bağlı olarak değişmektedir (Rath, 1992, 1994). Rath (1992) yaptığı çalışmada, konu uzmanlarının tecrübelerine dayanarak, Almanya iklim koşullarında yalıtımlı cam seralarda ortaya çıkabilecek maksimum sıcaklık yükselmesinin $7{ }^{\circ} \mathrm{C}$ alınabileceğini ifade etmektedir.

Rath (1994) yaptığı model çalışmasında gündüz saatlerinde serada ortaya çıkan sıcaklık ortalaması ile takip eden gecenin dış sıcaklık ortalaması arasındaki farka bağlı olarak, serada ortaya çıkan sıcaklık yükselmesini aşağıdaki ampirik ilişki (1) ile ifade etmiştir.

$\Delta \vartheta=\frac{1}{20} * S * Z$

İlişkide $s$, seranın özelliğine bağlı olarak 2-10 K arasında değişen bir katsayı, $Z$ ise gündüz saatlerindeki sıcaklık ortalaması ile takip eden gece saatlerindeki dış sıcaklık ortalaması arasındaki farkı ifade etmektedir.

Baytorun ve ark. (1995) yaptıkları çalışmada, Akdeniz iklim koşullarında (Adana) ısıtılmayan plastik serada gece saatlerinde ortaya çıkan sıcaklık yükselmelerini 
$-0.5{ }^{\circ} \mathrm{C}, 1.6^{\circ} \mathrm{C}$ arasında belirlemişlerdir. Von Zabeltitz (2011) Akdeniz ülkelerindeki seraların ısı enerjisi gereksinimini hesaplarken, seralarda ortaya çıkan sıcaklık yükselmesinin $1-2{ }^{\circ} \mathrm{C}$ alınabileceğini ifade etmektedir.

Seralarda ısı gereksinimi seranın donanımına göre değişmektedir. Seralarda kullanılan ısı perdelerinin sızdırmazlıkları ısı gereksinimine etki eder. Müller (1987) üretici seralarında yaptığı çalışmada ısı perdelerinin yalıtımına bağlı olarak tasarruf oranının anlamlı şekilde değiştiğini belirlemiştir. Rath (1992) Müller'in yaptığ perdelerinin yalıtımına bağlı olarak düzeltme katsayılarını geliştirmiştir.

Seralarda isitma sistemlerinin tipi ve seraya yerleştiriliş durumu da ısı tüketimine etki etmektedir. Isıtma borularının sera tabanına yakın yerleştirilmesi ısı kayıplarının azalmasina neden olurken, ısıtma borularının yükseğe yerleştirilmesi veya hava üfleyicili ısıtma sistemlerinin düşük kademelerde çalıştırılması, ısı tüketimini arttırmaktadır (Tantau, 1983).

Yukarıda belirtilen nedenlerden dolayı seralarda ısı gereksinimi, sera donanımına, serada ortaya çıkan gerçek sıcaklık değerleri ve seranın özelliğine bağlı ortaya çıkan sıcaklık yükselmesi göz önüne alınarak saatlik iklim değerlerinden (sıcaklık, radyasyon, rüzgâr hızı) gidilerek belirlenmelidir (Baytorun ve ark., 2016b; Rath, 1992; Tantau, 2008). Ancak bu hesaplamaların elle yapılması çok uzun zaman gerektirdiği gibi, kullanılan mantıksal ifadeler nedeniyle hemen hemen olanaksızdır. Son yıllarda geliştirilen "Uzman Sistemler" yardımı ile tüm mantıksal ifadelerin ve matematiksel ilişkilerin çok hızlı ve doğru şekilde çözümü mümkün olabilmektedir.

Uzman sistemler konusunda söz sahibi olan araştırıcılar, uzman sistemleri, çözümleri oldukça zor, karmaşık ve dikkat gerektiren problemlerin, bilgi ve kazanılmış tecrübelerle hazırlanmış bilgisayar programları ile çözümleyen akıllı programlar olarak tanımlamaktadır. Bu bilgi seviyesi programlama tecrübesiyle harmanlanarak oluşturulan modeller, bu konuda çalışan insanlar için kolaylıklar sağlamaktadır (Harmon ve King, 1989). Engesser (1993)'e göre uzman sistemler, özel bir alandaki bilgilerin toplanması, depolanması ve konu hakkındaki bilgiler yardımı ile oluşturulan programın, bu alandaki zor problemlerin çözümlenmesini sağlayan akıllı programlar olarak tanımlamaktadır. Nixdorf AG'nin konu hakkındaki uzmanı olan Savory (1988) uzman sistemleri, belli bir alandaki uzman bilgilerin depolanması ve yapay zekâya bağlı metotlarla problemleri çözümleyen, bilgisayar destekli karar verme aracı olarak tanımlamaktadır.

Uzman sistemlerle konvansiyonel bilgisayar programları arasındaki fark, uzman sistemlerde bilginin mantıksal formlarda ifade edilmesidir (Rath, 1992). Günümüzde bilgisayar teknolojilerindeki gelişmeler göz önüne alındığında çok karmaşık matematiksel ve mantıksal ilişkilerde bile hesaplama zamanlarının saniyeler düzeyine indirilebileceğini göstermiştir. Son zamanlarda daha önce yapılmış araştırmalar sonucunda kazanılan bilgi, deneyim ve sonuçların bilgisayar teknolojilerindeki gelişmeler ve ucuzlamalar da göz önüne alınarak kapsamlı bilgisayar programlarının (Uzman Sistemler) tarımsal alanlar da kullanıldığı görülmektedir (Rath, 1992). Göhler ve ark. (1989) özellikle bahçecilik ve tarım alanlarında, bitki koruma, sulama, gübreleme ve üretim ekonomisi hesaplamalarında geliştirilmiş uzman sistemlerinden bahsetmektedir. Üstün ve Baytorun (2003) sera projelerinin hazırlanmasına yönelik uzman sistemin oluşturulması konusunda çalışmalar yürütmüştür.

Baytorun ve ark. (2016b) seralarda 1sı gereksiniminin belirlenmesi ve isitma sistemlerinin projelenmesinde gerekli olan parametrelerin hesaplanması için ISIGER-SERA uzman sistemi geliştirmişlerdir. ISIGER-SERA modeli seralarda isı gereksinimini, saatlik iklim verilerinden giderek serada ortaya çıkan gerçek sıcaklık ve seranın özelliğine (cam, plastik) bağlı olarak ortaya çıkan sıcaklık yükselmelerine göre hesaplama yapmaktadır.

Yapılan bu çalışmada Adana iklim koşullarında üretici koşullarında yüksek donanıma sahip PE plastik serada gerçekte tüketilen yakıt miktarı ile ISIGERSERA modeliyle hesaplanan yakıt tüketiminin karşılaştırılarak ISIGER-SERA uzman sistem modelinin test edilmesi amaçlanmıştır.

\section{MATERYAL ve METOT}

Bu bölümde ISIGER-SERA uzman sistem modeli ve modelin test edilmesi için gerekli verilerin elde edildiği sera denemesi iki alt başlık altında açıklanmıştır.

\section{Modelin Tanıtımı ve Yapisı}

ISIGER-SERA uzman sistem modelinde yer alan matematiksel ilişkiler Rath (1992)'ın DIN 4701 standartlarına dayanan çalışmasından alınmıştır. Isı gereksiniminin hesaplanmasinda gerekli olan iklim parametreleri (sıcaklık, rüzgâr hızı ve güneş radyasyonu) Meteoroloji Genel Müdürlüğünden Türkiye'nin farklı illeri için sağlanan verilerden oluşturulmuş veri tabanından sağlanmıştır. Hesaplamalar web tabanlı PHP programlama dili ile hazırlanmış bir bilgisayar yazılımı tarafından hesaplanmıştır.

\section{Model Girdi Parametreleri}

ISIGER-SERA program menüsünde sera donanımı ve sera kurulacak yer tanımlanmaktadır. Sera donanımında örtü malzemesi, serada arzulanan ısıtma 
ve havalandırma sicaklık değerleri, enerji korunumu amacıyla kullanılan ısı perdesinin özellikleri, sızdırmazlığ sisteminin tipi, aydınlatma ve sera kurulacak yere ilişkin bilgiler girilmektedir.

ISIGER-SERA uzman sistem modelinde sera tipi olarak çatı tipi tanımlanabilirken, örtü malzemesi olarak cam, PC (Polikarbon) ve PE (Polietilen) örtü malzemesi seçilebilmektedir. Modelde sera çatısında ve yan duvarlarda farklı örtü malzemelerinin seçimi mümkündür. ISIGER-SERA uzman sistem modelinde serada gece ve gündüz farklı ısitma sicaklık değerlerinin verilmesi yanında, havalandırma sıcaklığı tanımlanarak ısıtma ve havalandırmanın çakışması önlenebilmektedir.

ISIGER-SERA uzman sistemin en önemli özelliklerinden biri serada isı tasarrufu amaciyla kullanılan ısı perdelerinin seçimi ve yönetimidir. Hesaplamalarda ısı perdelerinin açılması ve toplanması dış radyasyona, dış sıcaklığa ve istenirse zamana bağlı olarak yönetilebilmektedir. Isı perdelerinin sızdırmazlıklarına bağlı ısı tüketimleri Müller (1987)'in yaptığı araştırmalar sonucu elde ettiği katsayılara göre belirlenmektedir.

ISIGER-SERA uzman sistem modelinde serada kullanılan farklı ısıtma sistemleri için Tantau (1983)'da önerilen ısı gereksinim katsayılarına bağlı düzeltme katsayıları kullanılmıştır.

ISIGER-SERA uzman sistem modeli ile sera kurulacak yerin iklim değerleri 1962-2012 yılları arasındaki saatlik iklim değerlerinin ortalaması alınarak belirlenebilmektedir. Bu amaçla Meteoroloji
Genel Müdürlüğünden sağlanmış olan uzun yıllık sıcaklık, rüzgâr hızı ve güneş radyasyonu değerlerinden bir iklim veri tabanı oluşturulmuş̧ur.

\section{Model Çıktı Parametreleri}

ISIGER-SERA uzman sistem modeli ile yapılan hesaplamalar sonucunda elde edilen sonuçlar tablo ve grafikler şeklinde raporlanabilmektedir. Çıktı olarak yakıt miktarı, $\mathrm{CO}_{2}$ emisyonu, yılın günlerine haftalarına ve aylarına bağlı ısı gereksinimi, kurulacak isitma sisteminde gerekli boru uzunluğu, kazan kapasitesi ve kullanılacak pompa kapasitesi belirlenebilmektedir. Ayrica isitma sisteminde buffer tank kullanılması durumunda farklı kazan ve buffer tank kapasiteleri ile ylllık ısı enerjisi karşllanma yüzdesi hesaplanarak buffer tank ve kazan kapasitelerin optimizasyonu yapilabilmektedir.

ISIGER-SERA uzman sistem modelinin girdileri ve çıktıları genel akış diyagramı halinde Şekil 1'de gösterilmiştir.

\section{Sera Denemesi}

Araştırma Adana'da (35 E 18; 37 N 01) kurulu 20160 $\mathrm{m}^{2}$ büyüklügündeki yüksek teknolojiye sahip $\mathrm{PE}$ plastik serada yürütülmüştür. Seranın çatısı tek kat PE plastik $(180 \mu)$ yan duvarları çift katlı PC $(8 \mathrm{~mm})$ ile örtülmüştür. Çalışmada esas alınan seranın boyutları Çizelge 1'de verilmiştir. Isı gereksinimi hesaplamalarinda gerekli olan toplam isı iletim katsayısı $\left(U_{c s}\right)$ tek kat PE plastik için $7,0 \mathrm{~W} \mathrm{~m}^{-2} \mathrm{~K}^{-1}$, çift katlı polikarbon (PC-8 $\mathrm{mm}$ ) için $4,7 \mathrm{~W} \mathrm{~m}^{-2} \mathrm{~K}^{-1}$ olarak alınmıştır (Tantau, 1983; Von Zabeltitz, 1986).

Çizelge 1. Hesaplamalarda esas alınan PE plastik seranın boyutları

\begin{tabular}{|l|l|l|l|l|l|}
\hline Bölme sayısı & $($ Adet $)$ & 21 & Yan duvar alanı & $\left(\mathrm{m}^{2}\right)$ & 1000.00 \\
\hline Bölme genişlĭgi & $(\mathrm{m})$ & 9.60 & Cephe alanı & $\left(\mathrm{m}^{2}\right)$ & 2722.56 \\
\hline Sera uzunluğu & $(\mathrm{m})$ & 100.00 & Çatı alanı & $\left(\mathrm{m}^{2}\right)$ & 23617.76 \\
\hline Yan duvar yüksekliği & $(\mathrm{m})$ & 5.00 & Örtü alanı & $\left(\mathrm{m}^{2}\right)$ & 27340.32 \\
\hline Çatı yüksekliği & $(\mathrm{m})$ & 2.50 & Taban alanı & $\left(\mathrm{m}^{2}\right)$ & 20160.00 \\
\hline Mahya yüksekliği & $(\mathrm{m})$ & 7.50 & A $_{H} / \mathrm{A}_{G}$ & & 1.36 \\
\hline
\end{tabular}

Araştırmanın yürütüldüğü plastik sera düzenli olarak ısıtılmış ve ısıtmada ithal kömür kullanılmıştır. Serada $51 \mathrm{~mm}$ çapındaki ısıtma boruları sera tabanına yakın olarak bitki sıra aralarına döşenmiştir. Isıtmada kullanılan ithal kömürün alt ısıl değeri $\left(H_{u}\right) 8.14 \mathrm{kWh}$ $\mathrm{kg}^{-1}$ 'dır. Seradaki sıcaklık üç yollu dağıtıcı vanalar yardımıyla su sıcaklığının düzenlenmesi ile kontrol edilmiştir. Üretim periyodu boyunca tüketilen ithal kömür günlük olarak kaydedilmiştir. Günlük olarak tüketilen kömüre bağlı olarak seraya gönderilen ısı enerjisi 1 no'lu eşitlik yardımı ile hesaplanmıştır.

$Q=B_{y} * H_{u} * \eta$

Eşitlikte;

$\begin{array}{ll}Q & : \text { Isı enerjisi [kWh] } \\ B_{y} & \text { :Tüketilen kömür miktarı [kg] }\end{array}$
$H_{u} \quad$ :Kömürün alt ısıl değeri [kWh kg-1]

$\eta \quad$ :Isitma sisteminin randımanı [0.60 alınmıştır]

Araştırmanın yapıldığ 1 serada topraksız kültürde domates üretimi yapılmıştır. Seraya 2.5 adet $\mathrm{m}^{-2}$ domates fidesi dikilmiştir. Sulama her bir fideye tek bir damlatıcı gelecek şekilde spagetti damlatıcılarla otomatik olarak yapılmıştır. Serada ısı enerjisinin korunumu amaciyla XLS 15 is Svensonn) kullanılmıştır. Isı perdeleri güneş radyasyonu $0 \mathrm{~W} \mathrm{~m}^{-2}$ olduğunda kapatılmış, güneşin doğuşunu takiben 30 dakikalık süre içinde kademeli olarak toplanmiştır. 


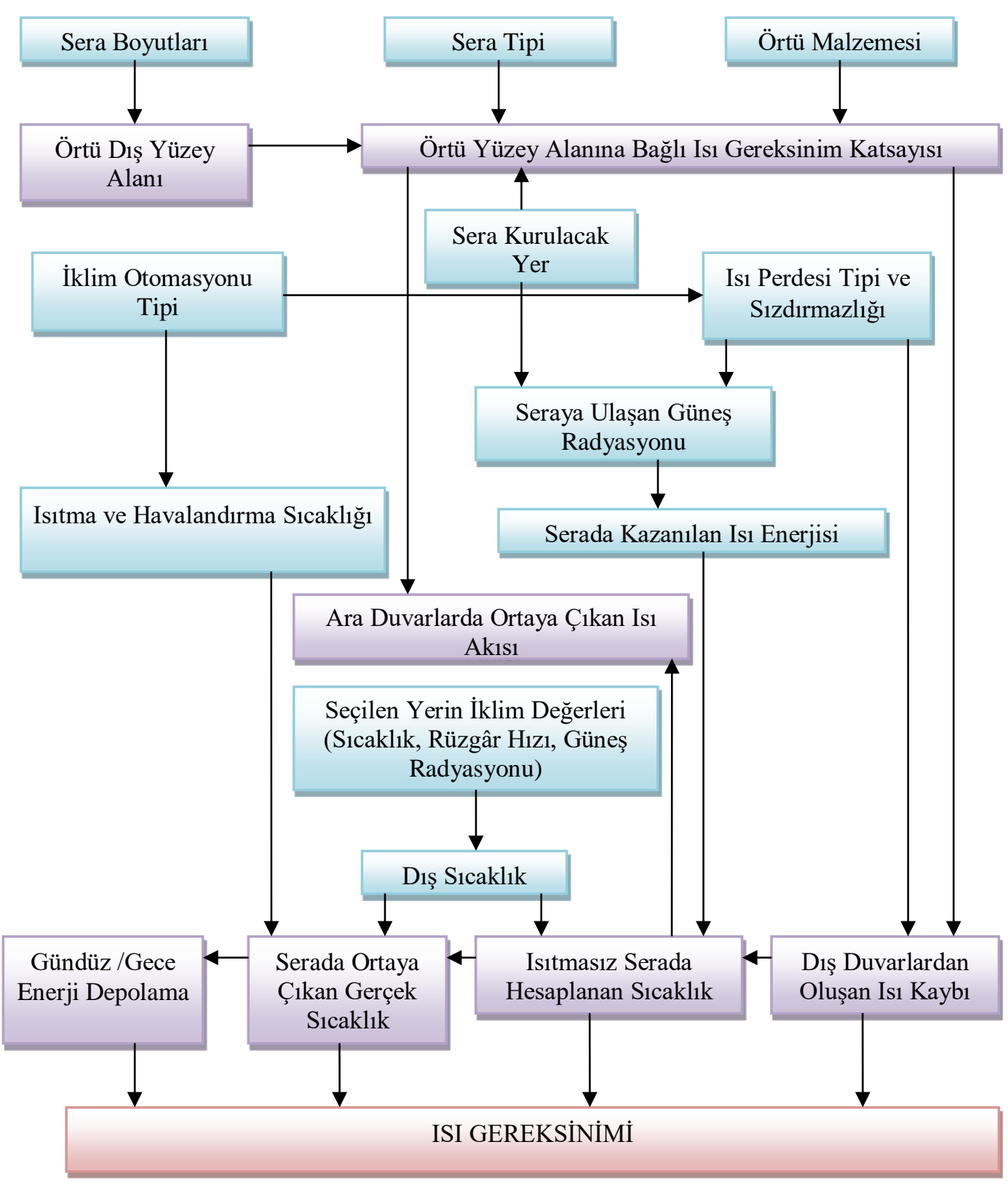

Şekil 1. ISIGER-SERA uzman sistem modelinde kullanılan akış diyagramı

Dış iklim değerleri ile seradaki sıcaklık, nem, güneş radyasyonu, su gidiş ve dönüş sıcaklıkları iklim bilgisayarı tarafından birer dakika aralıklarla ölçülüp birer saatlik ortalamalar halinde kaydedilmiştir. Serada sıcaklık ölçülen iklim değerlerine bağlı olarak denetim elemanları tarafından $16^{\circ} \mathrm{C}$ 'da tutulmuştur.

\section{BULGULAR ve TARTIŞMA}

Araştırmanın yapıldığ tarihinde başlanmış ve 30.03.2015 tarihinde son verilmiştir. Üretim periyodu boyunca serada tüketilen kömür miktarı Çizelge 2'de verilmiştir. Çizelgeden de görüleceği gibi üretim periyodu boyunca $20160 \mathrm{~m}^{2}$ büyüklüğündeki ısı perdeli serada sıcaklığın yaklaşık $16{ }^{\circ} \mathrm{C}$ 'da tutulmak istenmesi durumunda tüketilen toplam kömür miktarı $321500 \mathrm{~kg}$ olmuştur. $\mathrm{Bu}$ da birim sera alanı için $15.95 \mathrm{~kg} \mathrm{~m}^{-2}$ ithal kömüre eşdeğerdir. En yüksek kömür tüketimi Ocak ayında $(100775 \mathrm{~kg})$ ortaya çıkmıştır. Ocak ayında tüketilen kömür miktarı yıllık kömür tüketiminin \% 31.3’ünü oluşturmaktadır.

ISIGER-SERA uzman sistem modeliyle hesaplanan günlük ısı tüketimleri ile serada gerçek koşullarda tüketilen kömür miktarına bağlı hesaplanan isı tüketimleri Şekil 2'de verilmiştir. Şekilden de görüleceği gibi model yardımıyla günlük olarak hesaplanan ve serada gerçekte günlük olarak tüketilen ısı enerjisi değerlerinde farklılıklar görülmektedir. Bunun da nedeni ISIGER-SERA modeli ile teorik olarak yapılan hesaplamalarda kullanılan iklim verilerinin uzun yıllık ortalama saatlik değerler olması ve gerçek isı tüketimi 
ölçümlerinin yapıldığı 2014-2015 yılı iklim verilerinden günlük bazda farklılık göstermesinden kaynaklanmaktadır. Ortaya çıkan sapmalar daha sıcak olan geçiş dönemlerinde oransal olarak daha fazla olurken, soğuk dönemlerde bu sapmalar daha az olmuştur

Çizelge 2. Üretim periyodu boyunca $20160 \mathrm{~m}^{2}$ büyüklüğündeki PE plastik serada sıcaklığın $16{ }^{\circ} \mathrm{C}^{\prime} d a$ tutulmak istenmesi durumunda tüketilen kömür miktarı.

\begin{tabular}{|l|c|c|c|c|c|c|}
\hline \multirow{2}{*}{ Gün } & \multicolumn{2}{|c|}{2014} & \multicolumn{3}{c|}{2015} \\
\cline { 2 - 6 } & Kasım & Aralık & Ocak & Şubat & Mart \\
\hline Aylık toplam tüketim $\left(\mathrm{kg} \mathrm{ay}^{-1}\right)$ & 43700 & 71675 & 100775 & 67600 & 37750 \\
\hline Aylı̈k tüketim yüzdesi (\%) & 13.6 & 22.3 & 31.3 & 21.0 & 11.7 \\
\hline Yığışımlı tüketim (kg) & 43700 & 115375 & 216150 & 283750 & 321500 \\
\hline Yığışımlı tüketim (kg m$\left.{ }^{-2}\right)$ & 2.17 & 5.73 & 10.72 & 14.07 & 15.95 \\
\hline
\end{tabular}

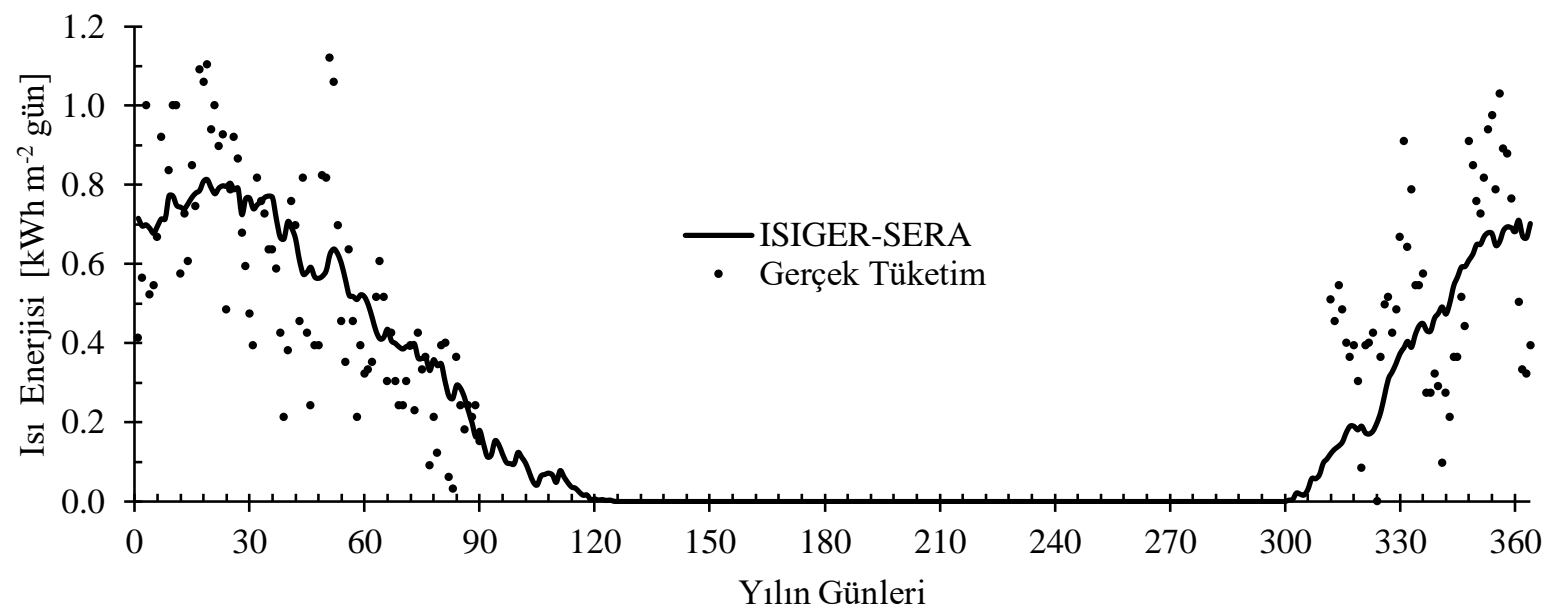

Şekil 2. Adana iklim koşullarında yüksek donanıma sahip ısı perdeli PE plastik serada sıcaklığın $16{ }^{\circ} \mathrm{C}$ 'de tutulmak istenmesi durumunda ISIGER-SERA uzman sistemle hesaplanan ve gerçekte tüketilen günlük ısı enerjisi değerleri.

Araştırmanın yapıldığı yüksek donanıma sahip PE plastik serada tüketilen günlük kömür miktarından gidilerek birim sera alanı için hesaplanan ve ISIGERSERA uzman sistem modeli ile yılın günlerine bağlı hesaplanan ısı tüketimleri Çizelge 3’te verilmiştir. Çizelgeden de görüleceği gibi birim sera alanı için tüketilen en yüksek isı enerjisi modele ve gerçek tüketime göre Ocak ayında ortaya çıkmıştır. Araştırmanın yapıldığı seranın birim alanı için Ocak ayında ISIGER-SERA modeline göre hesaplanan isı tüketimi $23.43 \mathrm{kWh} \mathrm{m}^{-2} \mathrm{ay}^{-1}$ olurken serada gerçekte tüketilen kömür miktarına göre hesaplanan aylık ısı tüketimi $24.43 \mathrm{kWh} \mathrm{m}^{-2}$ ay $^{-1}$ olmuştur.

ISIGER-SERA modeline göre hesaplanan ve gerçekte tüketilen ısı miktarları arasında aylara göre farklıklar ortaya çımıştır. ISIGER-SERA uzman sistem modeline göre hesaplanan ısı tüketimleri ile tüketilen yakıta bağlı olarak gerçekte ortaya çıkan ısı tüketimleri arasındaki farklılık soğuk dönemlerde azalırken, geçiş dönemlerindeki aylarda artmıştır.

Serada üretim periyodu boyunca aylara göre tüketilen kömür miktarı ile ISIGER-SERA uzman sistem modeline göre hesaplanan kömür tüketimleri Çizelge 4'te verilmiştir. Çizelgeden de görüleceği gibi, serada üretim periyodu boyunca gerçekte tüketilen kömür miktarı $15.95 \mathrm{~kg} \mathrm{~m}^{-2} \mathrm{a}^{-1}$ olurken, ISIGER-SERA uzman sisteme göre hesaplanan kömür tüketimi $15.45 \mathrm{~kg} \mathrm{~m}^{-2}$ $\mathrm{a}^{-1}$ olmuştur.

Üretim periyodu boyunca ISIGER-SERA uzman sistem modeline göre hesaplanan ve gerçekte tüketilen kömür miktarına göre hesaplanan ısı tüketimleri Şekil 3 'te verilmiştir. Şekilden de görüleceği gibi ISIGERSERA uzman sistem modeline göre hesaplanan isı tüketimi gerçek tüketimden $\% 3$ daha az bulunmuştur.

Adana iklim koşullarında yüksek donanıma sahip ısı perdeli PE plastik serada üretim haftalarına bağlı yığışımlı olarak gerçekte tüketilen ve ISIGER-SERA uzman sistem modeliyle hesaplanan kömür miktarları grafiksel olarak Şekil 4'te verilmiştir. Şekilden de görüleceği gibi ISIGER-SERA uzman sistem modeline göre hesaplanan ve gerçekte tüketilen kömür miktarı arasında büyük fark bulunmamıştır. ISIGER-SERA uzman sistem modeline göre tüm üretim periyodu için hesaplanan kömür tüketimi $15.45 \mathrm{~kg} \mathrm{~m}^{-2} \mathrm{a}^{-1}$ olurken, serada gerçekte tüketilen kömür miktarı $15.95 \mathrm{~kg} \mathrm{~m}^{-2}$ $\mathrm{a}^{-1}$ olmuştur. 
Çizelge 3. Adana iklim koşullarında yüksek donanıma sahip plastik serada yılın aylarına bağlı olarak ISIGERSERA Modeli ile teorik olarak hesaplanan ve serada gerçekte tüketilen günlük ısı enerjisi $\left(\mathrm{kWh} \mathrm{m}^{-2} \mathrm{gün}^{-1}\right)$ değerleri.

\begin{tabular}{|c|c|c|c|c|c|c|c|c|c|c|}
\hline \multirow[b]{2}{*}{ GÜN } & \multicolumn{2}{|l|}{ KASIM } & \multicolumn{2}{|l|}{ ARALIK } & \multicolumn{2}{|l|}{ OCAK } & \multicolumn{2}{|l|}{ ŞUBAT } & \multicolumn{2}{|l|}{ MART } \\
\hline & 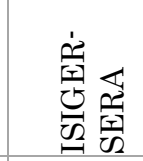 & 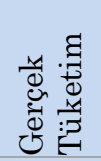 & 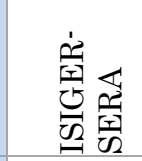 & 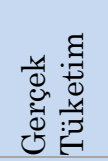 & 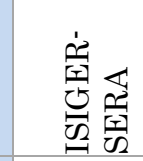 & 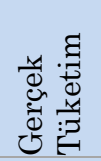 & 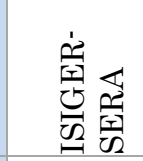 & 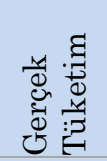 & 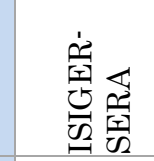 & 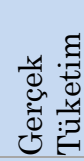 \\
\hline 1 & & & 0.44 & 0.55 & 0.72 & 0.41 & 0.75 & 0.82 & 0.52 & 0.32 \\
\hline 2 & & & 0.45 & 0.58 & 0.70 & 0.56 & 0.76 & 0.76 & 0.50 & 0.33 \\
\hline 3 & & & 0.43 & 0.27 & 0.70 & 1.00 & 0.77 & 0.73 & 0.46 & 0.35 \\
\hline 4 & & & 0.43 & 0.27 & 0.69 & 0.52 & 0.77 & 0.64 & 0.43 & 0.51 \\
\hline 5 & & & 0.46 & 0.32 & 0.68 & 0.55 & 0.77 & 0.64 & 0.41 & 0.61 \\
\hline 6 & & & 0.48 & 0.29 & 0.70 & 0.67 & 0.71 & 0.59 & 0.41 & 0.51 \\
\hline 7 & & & 0.49 & 0.10 & 0.71 & 0.92 & 0.67 & 0.42 & 0.44 & 0.30 \\
\hline 8 & 0.12 & 0.51 & 0.47 & 0.27 & 0.71 & 1.24 & 0.66 & 0.21 & 0.41 & 0.42 \\
\hline 9 & 0.13 & 0.45 & 0.50 & 0.21 & 0.77 & 0.84 & 0.71 & 0.38 & 0.40 & 0.30 \\
\hline 10 & 0.14 & 0.55 & 0.54 & 0.36 & 0.77 & 1.00 & 0.69 & 0.76 & 0.39 & 0.24 \\
\hline 11 & 0.15 & 0.48 & 0.57 & 0.36 & 0.75 & 1.00 & 0.66 & 0.70 & 0.39 & 0.24 \\
\hline 12 & 0.17 & 0.40 & 0.59 & 0.51 & 0.74 & 0.58 & 0.61 & 0.45 & 0.39 & 0.30 \\
\hline 13 & 0.19 & 0.36 & 0.59 & 0.44 & 0.74 & 0.73 & 0.57 & 0.82 & 0.39 & 0.39 \\
\hline 14 & 0.19 & 0.39 & 0.61 & 0.91 & 0.75 & 0.61 & 0.58 & 0.42 & 0.40 & 0.23 \\
\hline 15 & 0.18 & 0.30 & 0.62 & 0.85 & 0.77 & 0.85 & 0.59 & 0.24 & 0.36 & 0.42 \\
\hline 16 & 0.19 & 0.08 & 0.65 & 0.76 & 0.78 & 0.74 & 0.57 & 0.39 & 0.36 & 0.33 \\
\hline 17 & 0.17 & 0.39 & 0.65 & 0.73 & 0.79 & 1.09 & 0.56 & 0.39 & 0.36 & 0.36 \\
\hline 18 & 0.17 & 0.40 & 0.67 & 0.82 & 0.81 & 1.06 & 0.57 & 0.82 & 0.33 & 0.09 \\
\hline 19 & 0.18 & 0.42 & 0.68 & 0.94 & 0.81 & 1.10 & 0.58 & 0.82 & 0.36 & 0.21 \\
\hline 20 & 0.20 & 0.00 & 0.68 & 0.98 & 0.79 & 0.94 & 0.63 & 1.12 & 0.34 & 0.12 \\
\hline 21 & 0.23 & 0.36 & 0.65 & 0.79 & 0.78 & 1.00 & 0.64 & 1.06 & 0.35 & 0.39 \\
\hline 22 & 0.27 & 0.50 & 0.66 & 1.03 & 0.79 & 0.90 & 0.63 & 0.70 & 0.30 & 0.40 \\
\hline 23 & 0.31 & 0.51 & 0.68 & 0.89 & 0.80 & 0.93 & 0.60 & 0.45 & 0.27 & 0.06 \\
\hline 24 & 0.33 & 0.42 & 0.69 & 0.88 & 0.80 & 0.48 & 0.56 & 0.35 & 0.26 & 0.03 \\
\hline 25 & 0.35 & 0.48 & 0.69 & 0.76 & 0.80 & 0.79 & 0.52 & 0.64 & 0.29 & 0.36 \\
\hline 26 & 0.37 & 0.67 & 0.69 & 0.68 & 0.79 & 0.92 & 0.52 & 0.45 & 0.29 & 0.24 \\
\hline 27 & 0.39 & 0.91 & 0.71 & 0.5 & 0.79 & 0.87 & 0.51 & 0.21 & 0.26 & 0.18 \\
\hline 28 & 0.40 & 0.64 & 0.67 & 0.33 & 0.73 & 0.68 & 0.52 & 0.39 & 0.23 & 0.24 \\
\hline 29 & 0.39 & 0.79 & 0.67 & 0.32 & 0.77 & 0.59 & & & 0.20 & 0.21 \\
\hline 30 & 0.42 & 0.55 & 0.70 & 0.39 & 0.77 & 0.47 & & & 0.16 & 0.24 \\
\hline 31 & & & & 0.27 & 0.74 & 0.39 & & & 0.18 & 0.15 \\
\hline Top. & 5.65 & 10.56 & 17.83 & 17.36 & 23.43 & 24.43 & 17.69 & 16.37 & 10.84 & 9.08 \\
\hline
\end{tabular}

Çizelge 4. Adana koşullarında yüksek teknolojiye sahip ısı perdeli plastik serada sıcaklığın $16{ }^{\circ} \mathrm{C}$ 'da tutulduğu koşullarda ISIGER-SERA modeline göre hesaplanan ve serada gerçekte tüketilen kömür tüketimi.

\begin{tabular}{|l|l|l|l|l|l|l|}
\hline Kömür tüketimi $\left(\mathrm{kg} \mathrm{m}^{-2}\right)$ & Kasım & Aralık & Ocak & Şubat & Mart & Toplam \\
\hline Gerçek tüketilen & 2.17 & 3.56 & 5.00 & 3.35 & 1.87 & 15.95 \\
\hline ISIGER-SERA ile hesaplanan & 1.16 & 3.65 & 4.80 & 3.62 & 2.22 & 15.45 \\
\hline
\end{tabular}

Elde edilen sonuçlara göre ISIGER-SERA uzman sistem modeline göre hesaplanan yakıt tüketimim gerçekte tüketilen yakıt miktarına çok yakın olarak bulunmuştur.

ISIGER-SERA uzman sistem modeline göre hesaplanan ve gerçekte tüketilen yakıt miktarları dikimden sonraki haftalara bağlı olarak istatistiksel olarak değerlendirilmiş, elde edilen ilişkiler aşağıda verilmiştir. Her iki yönteme göre yapılan istatistiksel değerlendirmede yüksek korelasyon elde edilmiştir. 


\begin{tabular}{|l|l|l|}
\hline Gerçek Tüketim & $\mathrm{y}=-0.003 \mathrm{x}^{3}+0.091 \mathrm{x}^{2}+0.165 \mathrm{x}+0.188$ & $\mathrm{R}^{2}=0.999$ \\
\hline ISIGER-SERA & $\mathrm{y}=-0.003 \mathrm{x}^{3}+0.102 \mathrm{x}^{2}-0.011 \mathrm{x}+0.033$ & $\mathrm{R}^{2}=0.999$ \\
\hline
\end{tabular}

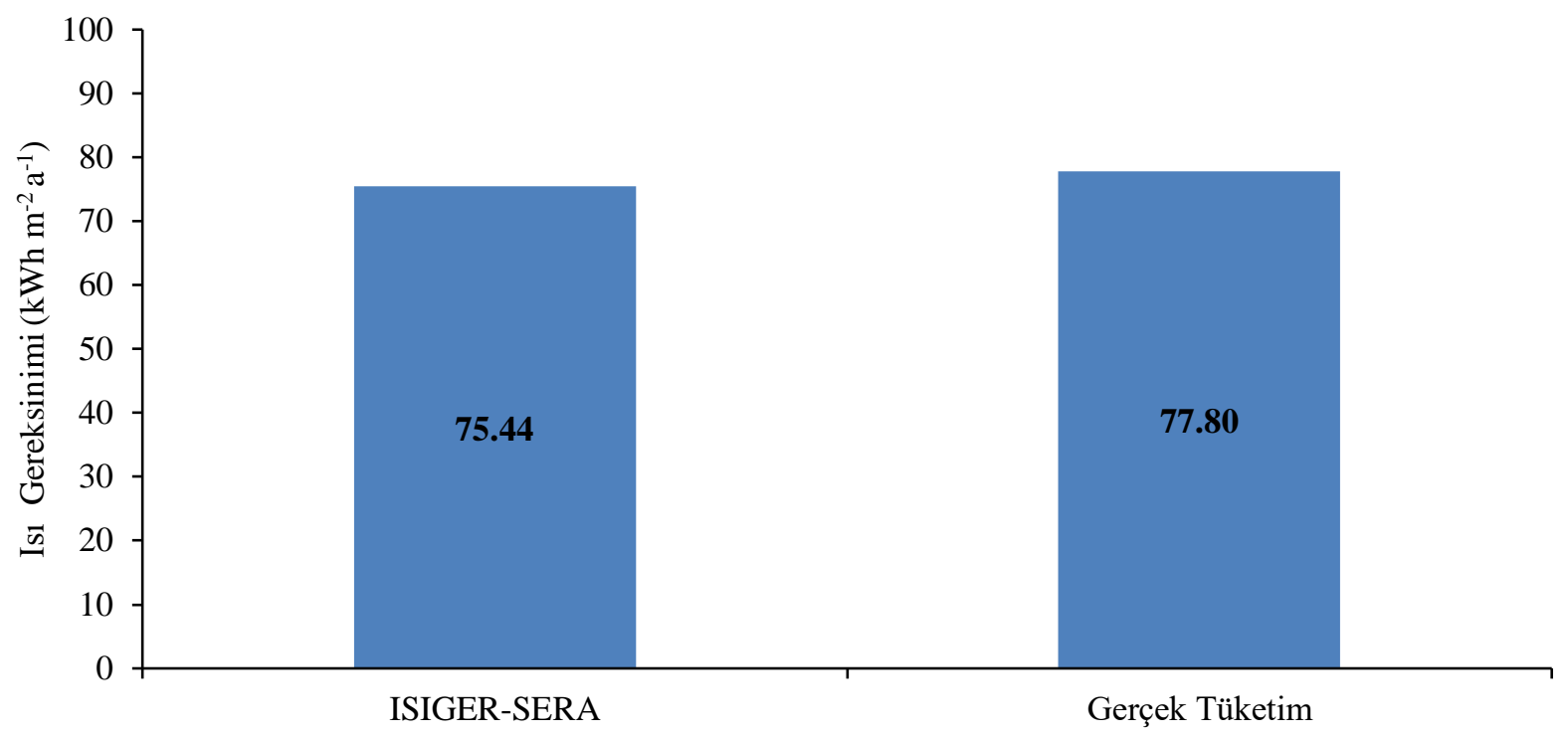

Şekil 3. Adana koşullarında yüksek donanıma sahip ısı perdeli PE plastik serada sıcaklığın $16^{\circ} \mathrm{C}$ 'da tutulmak istenmesi durumunda ISIGER-SERA uzman sistem modeline göre hesaplanan ve gerçekte tüketilen kömür miktarına göre hesaplanan ısı tüketim değerleri $\left(\mathrm{kWh} \mathrm{m}^{-2} \mathrm{a}^{-1}\right)$

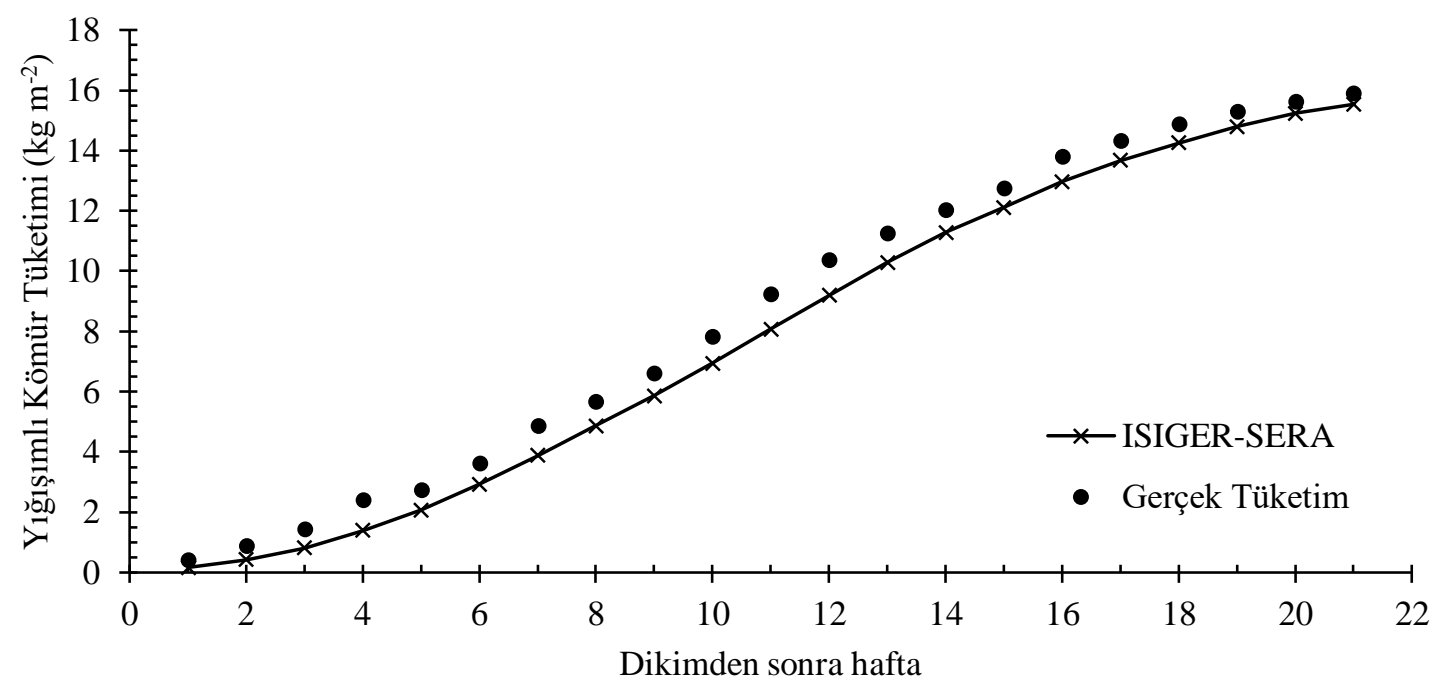

Şekil 4. Adana iklim koşullarında ısı perdeli PE plastik serada üretim periyodu boyunca tüketilen ve ISIGERSERA modeline göre hesaplanan yığışımlı kömür miktarı $\left(\mathrm{kg} \mathrm{m}^{-2}\right)$

\section{SONUÇ ve TARTIŞMA}

Seralarda ısı tüketimi saatlik değerlerden gidilerek hesaplanmalıdır. Günlük ortalama sıcaklık değerlerine göre yapılan hesaplamalar sağlıklı sonuçlar vermemektedir. Ayrıca literatürde verilen toplam ısı tüketim katsayıları $4 \mathrm{~m} \mathrm{~s}^{-1}$ rüzgâr hızı için geçerlidir. Isı gereksinimi hesaplamalarında toplam isı tüketim katsayısı $\left(U_{c s}\right)$ rüzgâr hızına bağlı olarak belirlenmeli, dış sıcaklık yerine belirli bir sıcaklığa kadar havalandırılmayan ve isitılmayan serada ortaya çıkan gerçek sıcaklık ve seranın özelliğine bağlı ortaya çıkan sıcaklık yükselmeleri göz önüne alınmalıdır. Açıklanan bu koşulları göre seralarda ısı gereksinimini hesaplayan ISIGER-SERA uzman sistem modeliyle Akdeniz iklim koşullarında hesaplanan isı tüketimleri gerçekte tüketilen isı tüketimleri çok iyi bir uyum göstermiştir. Elde edilen sonuçlar ISIGER-SERA uzman sistem modelinin seralarda ısı gücü ve ısı gereksinimi hesaplamalarında güvenli şekilde kullanılabileceğini göstermiştir.

\section{KAYNAKLAR}

Baytorun AN, Üstün S, Akyüz A, Çaylı A. 2017. The Determination of Heat Energy Requirement for Greenhouses with Different Hardware under Climate Conditions Antalya. Turkish Journal of 
Agriculture-Food Science and Technology, 5(2), 144-152.

Baytorun N, Abak K, Tokgöz H, Güler Y, Üstün S. 1995. Seraların kışın iklimlendirilmesi ve denetimi üzerinde araştırmalar. Türkiye Bilimsel ve Teknik Arasstirma Kurumu. Proje no TOAG-993.

Baytorun N, Akyüz A, Üstün S. 2016a. Sera Isitma Sistemlerinin Projelenmesinde Uzman Sistem "ISIGER-SERA". Tesisat Mühendisliğgi(155), 13-24.

Baytorun N, Akyüz A, Üstün S. 2016b. Seralarda isitma sistemlerinin modellemesi ve karar verme aşamasında bilimsel verilere dayalı uzman sistemin "ISIGER-SERA" geliştirilmesi. TÜBITAK 1140533 nolu proje.

Baytorun N, Zaimoğlu Z, Üstün S. 2012. Akdeniz Bölgesi Seralarında IsI Enerjisi Gereksiniminin ve Enerji Artırım Önlemlerinin Etkisinin Belirlenmesi. II. Ulusal Sulama ve Tarımsal Yapilar Sempozyumu, Bornova, İmir.

Canakci M, Emekli NY, Bilgin S, Caglayan N. 2013. Heating requirement and its costs in greenhouse structures: A case study for Mediterranean region of Turkey. Renewable \& Sustainable Energy Reviews, 24, 483-490. doi: 10.1016/j.rser.2013.03.026

Damrath J. 1980. Tabellen zur Heizenergieermittlung von Gewächshäusern Gartenbautechnische Informationen 8. Institut für Technik in Gartenbau und Landwirtschaft, Hannover, 8.

Damrath J, Klein LF. 1983. Tabellen zur Heizenergieermittlung von Gewächshäusern. Gartenbautechnische Information ITG Hannover. Heft 18 Klima Trier. . Institut für Technik in Gartenbau und Landwirtschaft, Hannover.

Engesser H. 1993. Duden Informatik; 2., vollst. überarb. und erw. Auflage, Dudenverlag Mannheim, Leipzig, Wien, Zürich.

Göhler A, Rath T, Schmidt PT. 1989. Chancen und Risiken von Expertensystemen. Taspo Magazin, 16 (11), s. 15-16.

Hallaire M. 1950. Les températures moyennes nocturnes, diurnes et nycthémérales exprimées en fonction du minimum et du maximum journaliers de température. Comptes Rendus Hebdomadaires Des Seances De L Academie Des Sciences, 231(25), 1533-1535.

Harmon P, King D. 1989. Expertensysteme in der Praxis. Perspektiven, Werkzeuge, Erfahrungen. 3. aktualisierte und ergänzte Auflage: Oldenbourg Verlag: München/Wien.

Meyer J. 2008. Nomenklatur und Definitionen Bericht zur Bestimmung und Bewertung des Energiebedarfs von Gewachshausern. KTBL Workshop. 17 September 2008, S.14-22.
Müller G. 1987. Energieschierme unter Praxisbedingungen Bewertung und Optimierung im Hinblick auf Energieverbrauch und Klimaführung. Dissertation. Institut für Technik in Gartenbau und Landwirtschaft Universitat Hannover.

Önder D. 1998. Hatay ili samandağ ilçesindeki seraların yapısal ve teknik yönden incelenmesi ve yöre seraları için ısı yükünün belirlenmesi. Yüksek lisans tezi. C.Ü.Fen Bilimleri Enstitüsü. Adana.

Öztürk H. 2011. Antalya Ikklimi Koşullarında Sera Isitma Amaciyla Güneş Enerjisinin Duyulur ISI Olarak Depolanması Için Tasarım Değişkenlerinin Belirlenmesi. İKLIM 2011 Ulusal İklimlendirme Kongresi, ANTALYA, TÜRKIYE.

Rath T. 1992. Einsatz wissensbasierter Systeme zur Modellierung und Darstellung von gartenbautechnischem Fachwissen am Beispiel des hybriden Expertensystems HORTEX. Gartenbautechnische Informationen (Germany). no. 34 .

Rath T. 1994. Einfluss der Warmespeicherung auf die Berechnung des Heizenergiebedarfs von Gewachshausern mithilfe des k'-Modells. Gartenbauwissenschaft 59 (1), s.39-44.

Savory SE. 1988. Grundlagen von Expertensystemen: Oldenbourg Munchen etc.

Tantau HJ. 1983. Heizungsanlagen Im Gartenbau.Handbuch Des Erwerbsgärtners. Stuttgart: Verlag Eugen Ulmer.

Tantau HJ. 2008. Wärmeverbrauchsmessung Einflussfaktoren. Bericht zur Bestimmung und Bewertung des Energiebedarfs von Gewächshäusern. KTBL Workshop. 17 September 2008. s.23-30.

Üstün S. 1993. Cukurova Bölgesinde Farklı Sera Içi İklim Koşullarında ISI Gereksiniminin Hesaplanması Üzerine Bir Araştırma. Çukurova Üniversitesi, Adana.

Üstün S, Baytorun AN. 2003. Sera Projelerinin Hazırlanmasına Yönelik Bir Uzman Sistemin Oluşturulması. KSÜ Fen ve Mühendislik Dergisi, 6(1), 168-176.

Von Zabeltitz C. 1986. Gewachshauser - Handbuch des Erwerbsgartners. Stuttgart: Ulmer -Verlag.

Von Zabeltitz C. 2011. Integrated Greenhouse Systems for Mild Climates: Climate Conditions, Design, Construction, Maintenance, Climate Control. Integrated Greenhouse Systems for Mild Climates: Climate Conditions, Design, Construction, Maintenance, Climate Control, 285-311. doi: 10.1007/978-3-642-14582-7_12. 